\title{
From Siti Zubaidah Lyric to Character Identification and Storyline Writing for Local Culture Revitalization
}

\author{
Rita Inderawati, Nurhayati
}

\begin{abstract}
Students of English Education Study Program read and learn English literature and some Palembang legends in their literature class. However, they never read lyric as local or traditional literature which is written in Melayu. In order to revitalize the local culture, they were introduced with the beautiful rhymes they never learnt before. They have to read and understand 3822 lyrics of Siti Zubaidah. This study aimed to investigate the students' ability in: (1) identifying the characters; (2) arranging story line after paraphrasing the lyrics; and (3) perceiving the importance of the lyrics as a revitalized local culture. Using descriptive qualitative method as one of the method used in this $\mathrm{R}$ and $\mathrm{D}$ research design with 41 students of the fifth semester as the sample, the researchers collected the data in forms of documentation, questionnaire, and interview. The data were analyzed by using percentage analysis and rubric of story writing. The results of this study showed that: (1) from the data, there were $37 \%$ or 15 students who categorized as Very Good, meanwhile there were $63 \%$ students who categorized as Excellent in identifying the characters of the lyric, (2) the storylines arranged by the students were categorized as good enough with the average score was 70 , and (3) there were $66 \%$ or 23 students who positively perceived the importance of lyric for the local culture revitalization.
\end{abstract}

Keywords - lyric, character identification, storyline, local culture revitalization

\section{INTRODUCTION}

Literature is inseparable with culture and is taught in English education study program. So far the study program makes use of English literature and some south Sumatra legends for students in literature classroom. Siti Zubaidah, one of the traditional performance arts of Palembang after being created from lyric, seems to have no audience. It is such kind of lyric which is performed all nights long and provides with moral lessons the audience can obtain. This lyric is freely performed by adult artists without any efforts to revitalize it. In order that young generation will be able to know their own culture; therefore, this study did some crucial things for the sustainable revitalization in order to preserve Siti Zubaidah in this modern era. As parts of revitalizing art performance, young generation should be involved as they are the ones who will be going to share and tell it in the future; otherwise, it will stay virtually unknown for the next generation (Nurhayati, Subadiyono, and Suhendi, 2014, p.2).

Sriwijaya University, South Sumatra, Indonesia, Email: ritarudisaid@yahoo.com
Dulmuluk Theater is a traditional theater that was born in Palembang, South Sumatra., Indonesia. The origin of this theater was a form of poetry readings by Wan Bakar who read poetry about Abdul Muluk. To make it more interesting, it was then presented by several people and accompaniment. There were various reasons why the traditional theater did not lead to creative industries and was eventually abandoned by society. Nurhayati (2011) found that the students of Indonesian Language and Literature Study Program of Education Faculty Sriwijaya University put forward their opinion dealing with the existence of the traditional theater as follows. First, they generally never acquainted the name of Dulmuluk. Second, several aspects such as; monotonous story line, unprofessional directing, and outdated appearance of performers did not attract the audiences. Nurhayati (2011) also asserts that out of 36 students, only 12 (33\%) who were interested in watching the performance until it was finished, the others left the venue before the performance was done. It is in line with the study done by Lelawati (2009) that revealed various reasons of why Dulmuluk is abandoned; it is not only caused by the popular culture and modern technology but also due to the lack of organization and performance management.

Revitalization of Siti Zubaidah traditional performance is one part of the preservation of traditional arts. The concept of conservation includes four main components, namely the preservation, restoration/rehabilitation, reconstruction and revitalization (Puspari, 1997:196).

Revitalization is an attempt to change a kind of tradition art adapted to the development of society and has new functionality without losing the spirit of the arts (Komala, 2003). Revitalization of Siti Zubaidah is intended to explore and give new meaning to the art of it without changing the substance and form. When it was previously served as entertainment in the organization of local communities' customary event, then in the present context its functions need to be adjusted to the needs, for example, be used as early introduction for the students of English Education Study Program.

By making use of the Siti Zubaidah lyrics, the English Education Study Program students were introduced to the traditional art for the sake of reserving and revitalizing. The nurturant effect of the early introduction was the lyric could be introduced to international community through some stories written by the students in English version after they identified 
the characters and paraphrased the storyline during one semester.

Regarding the cultural processes and strategies or patterns used, it is necessary to refer to the notion of culture proposed by Peursen (1988, p. 233) that culture actually is not a noun, but a verb. In other words, it is the work of our own culture, our own responsibility. Thus, the culture is functionally described as a relation to the plan of our own lives. Culture then appears as a giant learning process that is being executed by the human race. Culture does not happen outside of humans'; they themselves must find a cultural strategy. It is a process of preserving the culture in which it will in fact lead to behavioral culture by itself if is perpetually done within a certain time.

Furthermore, literature does not only have the value of pleasure, but also simultaneously educating people. By reading and listening to literary works, someone could gain experience and new understanding about many things. This will broaden the horizon of someone because literature can be for education and entertainment needs. According to Stewig (1980), one of the benefits or values of literature is it can be a good effect for students' personality development. Furthermore, Huck et. Al (1987) argue that the value or benefit of literature, including drama/theater can be grouped into two categories; (1) personality (personal value) and (2) the value of education (educational value). Supriyadi (2006) explains that in addition to having the benefit of personality development and education, literary works are also beneficial in improving language ability and writing skills. Similar to this, Inderawati $(2001,2005,2007,2008,2012,2013)$ found that literary works did not only help students enhance their ability in speaking and writing, but also establish their character. Moreover, students can study a range of subject areas, including language, social science, science, and citizenship (Inderawati, 2012). Additionally, Inderawati (2012: p.21) discovered that $89 \%$ of 438 Sriwijaya University students from different faculties agreed that literature had to be taught in their faculty in order to characterize and humanize themselves after responding to a literary work by applying a literary appreciation instrument and fulfilling a questionnaire developed by Inderawati (2012). As a result, it was strongly agreed by $95.1 \%$ of the students that literary works led them develop their character to be better (Inderawati, 2012:p.21).

Based on the previous depiction, this study focused on how the students identified the character and arranged the storyline towards Siti Zubaidah. It, hopefully, can help them comprehend the importance of the lyrics. Therefore, this study was aimed to know the students' ability in: (1) identifying the characters; (2) arranging storyline after paraphrasing the lyrics; and (3) perceiving the importance of the lyrics as a revitalized local culture.

\section{LITERATURE REVIEW}

\section{A. Dulmuluk Theatre}

Achmad (2006) puts forwards that Dulmuluk theater is a traditional theater in South Sumatra. Dulmuluk departed from the traditional theater in the form of oral literature rhymes or poems. Starting from memory in the form of storytelling which then produces a form called theater or the show as the first simplest theater where narrator tells to be heard by a group of spectators who attend in a show, then evolve into the show that is accompanied by music. In addition to this, Saleh (1996, 2732) cites that the establishment of the theater is undergoing various stages of Dulmuluk:

1. In the beginning of the stage, it is the poetry reading which is also called as the first theater.

2. In the second stage the poem is read by several people alternately based on the dialog cast.

3. The third phase of dialogue no longer read, but pronounced to be memorized. This stage begins with acting and wearing simple costumes.

4. In the fourth stage of the traditional theater, Dulmuluk is started playing in the fields and is no longer at the top of the stage. Costumes worn already complete as Dulmuluk recently watched.

5. The fifth stage, the Japanese government used Dulmuluk theater as a tool of propaganda because they know people go to the theater.

6. The sixth stage, due to the theater conditions, Dulmuluk starts using all modern equipment.

\section{Revitalization of Local Culture and Functional Approach}

Many forms of performing arts are under threat today. As cultural practices become standardized ones, many traditional practices are abandoned. Even in some cases where they become more popular, only certain expressions may benefit while others suffer. Elsewhere, other forces are at work, for example, some of the traditional arts survive (at least in part) because of the efforts of academic institutions to both preserve old practices and train a new generation of practitioners. Meanwhile, all cultural activities serve to satisfy a series of human instinctive life needs related to their life (Ihromi, 1999). In order to attract all people, revitalization should be made, adapted to the needs and development of society.

Art, as an element of culture in human life, has a function in which there are instruments of the model of cognition, symbolic system or historically transmitted delivery of symbols. Art is an expression of one form of creativity itself. Indriyanto (2002) mentions at least nine functions: 1) as a means of ceremonies; 2) entertainment functions, 3) the function of communication tools, 4) the function of symbolic offerings; 5) maintaining the norms of society; 6) as an affirmation of religious ceremony; 7) as a means of cultural continuity and stability, and 8) for the integrity of the community.

Nurhayati (2014) states that a Dulmuluk performance also pays attention to the suggestions put forward by Dulmuluk groups during the revitalization of the play to focus on the following elements of (1) the length of time the show needs to be shortened for just one hour, (2) the existence of a play primarily for conservation purposes, (3) the presence of a director who can provide interpretation and colors of the role and performance, (4) the existence of cosmetology for supporting roles, (5) the presence of the selection of players based on roles, (6) the election fashion in accordance with the role/character figures, (7) the existence of setting the stage, (8) the presence of lighting arrangements that support the story, 
(9) there is a sound system use including the music that supports the story, and (10) the presence of an audience. These elements are the parameters of revitalization.

\section{B. The Concept of Culture Revitalization}

Revitalization is derived from the word sustainable, which means it is remain forever unchanged. It could also be defined as an attempt to retain something in order to remain as it is. More details, Widjaja (1986) defines revitalization as an activity that performed continuously, focused and integrated in order to realize certain goals that reflect the existence of something consistent and immutable, dynamic, flexible and selective. Regarding the revitalization of local culture, Ranjabar (2006) suggests that to maintain art and culture values and traditional values by developing the dynamic manifestation, as well as adjusting to the situation and the ever-changing conditions and growing.

In relation to the the cultural revitalization, Alwasilah (2006) proposes three steps of implementing the sustainability of a culture, namely: (1) understanding to raise awareness, (2) planning collectively, and (3) generating of cultural creativity. Preservation is an effort that is based, and is also called the basis of the factors that support both from within and from outside of it is preserved. Therefore, a process or act of preservation techniques or strategies based on the needs and circumstances of each. Furthermore, Soekanto (2003, p.432) asserts that sustainability may not stand alone, because it always pairs with the development of survival. Sustainability is an aspect of human life stabilization, whereas the survival is a reflection of the dynamics.

This concept is essential for the student to keep the traditional art alive. Before performing the developed lyric into a play later on, they have to identify the whole characters and their characterization and to paraphrase the 3822 lyrics into some distinct storylines. Therefore, having worked on the two aspects, the students contribute the very necessary thing of conducting a revitalization toward the lyrics of Siti Zubaidah.

\section{Elements of Art Performance}

As a literature genre, the performance script is written in a compelling and memorable ways. The language is written using language as a poem, full of rhythm and beautiful sound. In addition, the language must depict human characters, sharp, and displays event full of surprises (Effendi, 2002: 2). In the performance, there are several elements:

Plot or Storyline

Plot is a construction made of logical and chronological events are interrelated and caused or experienced by actors while event is defined as a transition from one state to another state. That is, one event caused another one. From there, it develops into a conflict and climax which is essentially determined by the first event.

\section{Characterizations}

The characters are also a source action and conversation. According to Gazali (2001, p. 58) characters can be divided into several types, among others, the protagonist, antagonist, tritagonist and supporting role. All these types of figures are a series that cannot be separated because between characters with the other ones have the duty and full responsibility for accordance with the theme or purpose of the story to be achieved.

\section{Dialog}

Characteristic of the drama is the text form of dialogue. In preparing the dialogue, the author must pay attention to the characters. Dialogue should be aesthetically pleasing, it means should have the beauty of language, is able to influence the philosophy and beauty (Waluyo, 2002: 20-21). Dialogue is not just a conversation between characters, but the dialogue is a reflection of the thoughts and feelings of the characters that play a role in a drama.

\section{E. Setting}

Setting is the environment in which to express the characters and the events occurred. Setting the place does not stand alone but is related to time and space. It is also associated with costumes, stage, makeup, and other equipment if the script staged. Time should also be adjusted with the room and the place, time is the era or period in which the play (Waluyo, 2002).

\section{F. Theme}

The theme will be developed through a dramatic structure in the plot through the protagonists and antagonists with a disposition that allows the conflict and formulated in the form of a dialogue (Waluyo, 2002).

\section{Method AND PROCEDURES}

This study used descriptive qualitative method as a part of $\mathrm{R}$ \& D research design. The sample was 41 students of English Department students of Sriwijaya University Palembang, Indonesia. They were asked to watch a video of Siti Zubaidah, and then they worked individually and in group to identify characters and to write some storylines, they also have to respond the questions of the distributed questionnaire.

They were divided into three groups and the 3822 lyrics of Siti Zubaidah were also divided into three parts. They individually read the whole lyrics of each part before identifying the characters and characterizations, paraphrasing the lyrics and writing their own version of storylines. They then were grouped to discuss their findings. Furthermore, an open questionnaire to obtain data related to revitalization was administered in order to find out students' perceptions related to the intrinsic elements of the lyrics. The data were presented in the form of percentage analysis. The last instrument used was interview to obtain their opinion dealing with the process of identifying the characters and writing storylines.

The following is the grading system and figure of students' grade of character identification.

\begin{tabular}{|c|c|}
\hline $\begin{array}{l}\text { Range of Character } \\
\text { Identification }\end{array}$ & Grade \\
\hline $0-14$ & Poor \\
\hline $15-29$ & Good \\
\hline $30-44$ & Very Good \\
\hline $45-59$ & Excellent \\
\hline
\end{tabular}




\section{FINDINGS AND DISCUSSION}

\section{A. Character Identification}

From the students' discussion in figuring out the characters in Siti Zubaidah, it can be concluded that the students showed their understanding by finding $32-53$ characters in 3822 lyrics. From the data, there were $37 \%$ or 15 students who could identify the 32 characters, therefore they were categorized as Very Good, meanwhile there were $36 \%$ or 14 students who could identify 42 characters and there were $27 \%$ or 12 students who could identify until 53 characters. Therefore, there were $63 \%$ students who categorized as Excellent.

This is a positive feedback the students give towards the revitalization by following the storyline and obtaining the characters. Aside from that, the students could also notice the personality of each character by following the lyrics. They mentioned about three until five characteristics showing that they comprehend the lyrics and characterization.

It could also be concluded that the $37 \%$ students who were categorized as Very Good were able to identify the character they just confused in following the lyrics so they got some characters switched or incorrectly wrote one character for another.

From the students' discussion in figuring out the characters in Siti Zubaidah lyrics, it can be concluded that the students showed their understanding by finding 32-53 characters in 3822 lyrics. From the data, there were $37 \%$ or 15 students who could identify the 32 characters, therefore they were categorized as Very Good, meanwhile there were $36 \%$ or 14 students who could identify 42 characters and there were $27 \%$ or 12 students who could identify until 53 characters. Therefore, there were $63 \%$ students who categorized as Excellent.

This is a positive feedback the students give towards the Dulmuluk revitalization by following the story line and obtaining the characters. Aside from that, the students could also notice the personality of each character by following the lyrics. They mentioned about three until five characteristics showing that they comprehend the lyrics and characterization.

It could also be concluded that the 37\% students who were categorized as Very Good were able to identify the character they just confused in following the lyrics so they got some characters switched or mistakenly wrote one character for another.

The character identification was used at the very beginning of meeting to help students getting engaged to the lyrics. By knowing all the characters in the lyrics, the students could know their influence to the other elements of the lyrics (such as plot, setting, theme, etc.). Following are the grading system and figure of students' grade of character identification.

\begin{tabular}{|l|l|}
\hline $\begin{array}{l}\text { Range of Character } \\
\text { Identification }\end{array}$ & Grade \\
\hline $0-14$ & Poor \\
\hline $15-29$ & Good \\
\hline $30-44$ & Very Good \\
\hline $45-59$ & Excellent \\
\hline
\end{tabular}



Fig. 1: Students' grade based on the scoring system for character identification

\section{B. Writing Storyline}

The storyline that students wrote can be categorized as Very Good and Good; almost all the students gave a good result by noticing all the elements of the lyrics, and insert it into a new version of storyline. They did not leave the original setting, theme, and characteristics although they wrote the story to their own style.

From the first group, their writing was categorized as Very Good because their writing includes all the intrinsic element of art performance, including the appropriate settings, dialog, and plot in accordance with the original lyrics. For the second group, their writing could be categorized as Good level. They have already comprehended the composition of story line although they lack of putting some dialogs for certain setting. Meanwhile, the third group was categorized as Very Good. Their work was almost the same with the first one but they different settings and dialogs.

From the students' work, it can be concluded that the students could comprehend the Siti Zubaidah lyrics, they could follow the plot and theme and put the right characters into the story line. Moreover, they did not leave the true message of the lyrics into their new story line instead they gave a new atmosphere into the story where it felt more interesting to read. It can be seen that all the students achieved the lyrics during the treatment; it can be proved from their writing that did not go out of the theme.

What interesting from the students' work was that their writings were not so "narrow and awkward." From those who read the lyrics for the first time it may be difficult to understand the traditional lyrics which have the sense of "oldfashion", but the students could amazingly adjust to the lyrics and got the message of it.

\section{Storyline Writing}

The storyline that students wrote could be categorized into as Very Good and Good; almost all the students give a good result by noticing all the elements of the lyrics, and insert it into a new version of storyline. They did not leave the original setting, theme, and characteristics although they wrote the story to their own style.

From the first group, their writing was categorized as Very Good because their writing included all the intrinsic element of art performance, including the appropriate settings, dialog, and plot in accordance with the original lyrics. For the second group, their writing could be categorized as Good level. They have already comprehended the composition of storyline although they lacked of putting some dialogs for certain setting. Meanwhile, the third group was categorized as Very Good. Their work was almost the same with the first one but they had different settings and dialogs.

From the students' work, it can be concluded that the students could comprehend Siti Zubaidah lyrics. They could follow the plot and theme and put the right characters into the 
storyline. Moreover, they did not leave the true message of the lyrics into their new storyline instead they gave a new atmosphere into the story where it was felt more interesting to read. It can be seen that all the students achieved the lyrics during the process of teaching and learning in literature classroom; it can be proved from their writing that did not go out of the theme.

What interesting from the students' work was that their writings were not so "narrow and awkward." From those who read the lyrics for the first time it may be difficult to understand the traditional lyrics which have the sense of "oldfashion", but the students could amazingly adjust to the lyrics and got the message of it. It happened because the lecturer introduced and explained the lyrics step by step in every meeting by (1) watching a short video of Siti Zubaidah, (2) reading the 3822 lyrics, (3) discussing in group the characters and characterization, and (4) paraphrasing the lyrics.

\section{Perceiving the Importance of Lyrics}

At the end of the meeting, the students were given a questionnaire about their perception of Siti Zubaidah lyrics they have watched and asked their opinion about how the performance should be like in the future. Based on the data obtain from the questionnaire, there were three students who have watched Dulmuluk performance more than once (three times) while the other 32 students watched the performance for the first time in the class. Students who have watched it for three times said that although the performance was boring and out of date, it was still interesting because the performers brought the lyrics in unique ways.

Furthermore, there were $34 \%$ or 12 students who thought that Dulmuluk performance was the reaction of the audience during the performance was not excited, they also added that it was outdated and not updated; the performance was so historical, therefore, it needed some adjustments for the intrinsic elements and technology used. Meanwhile, there were $66 \%$ or 23 students thought that the performance was attractive for the audience since they rarely watched this traditional performance nowadays and its historical performance gave a variance to the art performance in this modern era.

At last, all the students found that Siti Zubaidah lyrics needed to be preserved as a local culture. They suggested that there some ways that could be done; introducing as local content in the schools and implementing the performance at least once a month so that it will be continuously known by the young generation and people around Palembang and South Sumatera. Out of all, the students perceived the importance of the lyrics, they care that Siti Zubaidah should be acknowledged as cultural heritage and should be introduced to the wide community as local culture from Palembang.

Through a depth-interview concerning with their activity in class to identify and to write storyline of the lyrics, all of them really agreed that by so doing, students and young generation in general have contributed to preserve the traditional arts, to love their own culture, to create into marvelous art performance.

\section{INTERPRETATIONS}

From this study, it can be concluded that the students barely know about Dulmuluk, they just happened knowing the name with having no knowledge about it. It is because Dulmuluk has slowly left by the people around Palembang because the performance itself does not make some improvement to attract audience. It is in line with the statement from Nurhayati, Subadiyono, and Suhendi (2014) that Dulmuluk will remain unknown if there is no adaptation to creative industry. Furthermore, aspects of clothing, make up, hairdressing, lighting and sound systems are not managed professionally. That is why people found Dulmuluk performances was so monotonous, boring and old-fashion. On the other hand, it is necessary to maintain Dulmuluk as a regional asset with revitalization in many ways. In this case, Siti Zubaidah lyrics is another asset of Palembang besides Dulmuluk.

One of the efforts in maintaining the existence of Dulmuluk/Siti Zubaidah is to introduce it to young generation. According to Lelawati (2009) the introduction of Dulmuluk can be done by the development process of structural theory and reader response. Therefore, the writer conducted this study by introducing the Dulmuluk performance to the college students and asked for their responses in identifying the characters and writing a story line.

\section{CONCLUSION}

Having read, understood, and discussed 3822 lyrics of Siti Zubaidah, it can be found that the students' ability in (1) identifying the characters; (2) arranging storyline after paraphrasing the lyrics and (3) perceiving the importance of the lyrics as a revitalized local culture were categorized good. It was such an early introduction to them to revitalize the local culture.

\section{REFERENCES}

[1] A.C. Alwasilah, Pokoknya Sunda: Interprestasi Untuk Aksi. Bandung : Kiblat. 2006.

[2] A.W. Widjaja, Pengantar Administarasi Kepegawaian. Jakarta:Rajawali. 1986.

Effendi, Telaah drama. Yogyakarta: FBS UNY. 2002

[3] A.S. Ghazali, Mempersiapkan pementasan drama: latihan tahan awal. Malang: Universitas Negeri Malang. 2001.

[4] C.S. Huck, S. Hepler and J. Hickman, Children's Literature. New York: Holt, Rinehart, and Wiston, Inc. 1987.

[5] T.O. Ihromi, Bunga Rampai Sosiologi Keluarga. Jakarta: Yayasan Obor Indonesia. 1999.

[6] R. Inderawati, Literature instruction in EFL classrooms: An ethnographic study of promoting students' literary appreciation and language skills at the English department of UPI Bandung. Unpublished Thesis at UPI Bandung. 2005.

[7] R. Inderawati, "Keefektifan Model Respons Pembaca dan Simbol Visual dalam Pembelajaran Sastra di SD." Makalah. Dipresentasikan dalam Konferensi Internasional Himpunan Sarjana-Kesusasteraan Indonesia (HISKI) XVI di Palembang, 18-21 Agustus 2005.

[8] R. Inderawati, Web-Based Literature: Displaying Students' Response to Short Story. In: The 55th Teflin International Conference. Teflin International. ISBN 978-979-17336-0-1. 2007

[9] R. Inderawati, Paradigma baru pengajaran apresiasi sasrta Indonesia. Makalah yang dipresentasikan dalam Kongres Internasional Bahasa Indonesia di Jakarta, 28 Oktober-1 November 2008. Diakses di http://www.jendelasastra.com/wawasan/artikel/paradigma-barupengajaran-apresisi-sastra-indonesia. 2008 
[10] R. Inderawati, A response to Tolstoy's God Sees the Truth, but Waits for character building of English Study Program Students of Sriwijaya University. Journal of Teaching and Education, 1 (04). ISSN 21566266. 2012

[11] R. Inderawati. The Application of Literature for All And Literature Across Curriculum Concept by Responding Literary Works to the Enlightenment of Character Education In Indonesia Context. Journal of Teaching and Education, 2 (1). 2013. pp. 13-24.

[12] Indriyanto, Lengger Banyumasan: Kontinuitas dan Pembahasan. Semarang: IKIP Semarang Press. 2002.

[13] L.R. Komala, "Peranan Nilai-nilai Tradisional dalam Kehidupan Modern dan Integritas Bangsa", naskah pidato pembukaan Simposium Nasional "Peranan Nilai-nilai Tradisional dalam Kehidupan Modern dan Integrasi Bangsae", tanggal 13 Januari di Surakarta (kerjasama Forum Komunilasi dan Informasi Keraton Nusantara dan Bappenas). 2003.

[14] N. Lelawati. Manajemen Organisasi dan Pementasan Teater Tradisional Dulmuluk di Palembang (Unpublished master's thesis). University of Sriwijaya, Palembang, Indonesia. 2009.

[15] Nurhayati, Subadiyono, and D. Suhendi, Seni pertunjukan tradisional dulmuluk:revitalisasi and apresiasi mahasiswa. Litera, (14)2, 229-238. 2014.

[16] C.A. Peursen, Stategi Kebudayaan. Yogyakarta: Kanisius. Retrieve from http://samanui.wordpress.com/2007/10/17/ sedikit-tentang-tarian-saman/ 1988.

[17] Puspasari, Penelitian Pengembangan Kesenian Tradisional. Final Report. Jakarta: Proyek Penelitian dan Pengembangan Bidang Kebudayaan dan Pariwisata Kementrian Kebudayaan. Kementrian kebudayaan dan Pariwisata RI. 1997.

[18] J. Ranjabar, Sistem Sosial Budaya Indonesia. Bogor :Ghalia Indonesia. 2006.

[19] Saleh, and R. Dalyono, Kesenian Tradisional Palembang: Teater Dulmuluk. Proyek Pembinaan dan Pengembangan Kesenian Tradisional Palembang. 1996.

[20] S. Soekanto, Sosiologi Suatu Pengantar. Jakarta: Rajawali Pers. 2003.

[21] J.W. Stewig, Read to write: using children's literature as a springboard for teaching writing ( $2^{\text {nd }}$ ed.). New York: Holt, Rinehart. 1980.

[22] Supriyadi, Pembelajaran sastra yang apresiatif dan interaktif di sekolah dasar. Jakarta: Depdiknas Dirjen Dikti Direktorat PPTK dan KPT Pendidikan Guru Sekolan Dasar. 2006.

[23] Waluyo, Drama teori dan pengajarannya. Yogyakarta: PT Hanindita Graha. 2001.

[24] R. Welle, Teori Kesusasteraan. Jakarta: P.T Gramedia Pustaka Utama. 1995. 